\title{
Post-Accession Policy-Making in Bulgaria and Romania: Can Non-state Actors Use EU Rules to Promote Better Governance?*
}

\author{
ANTOANETA DIMITROVA' ${ }^{1}$ and ARON BUZOGÁNY²
}

${ }^{1}$ Leiden University. ${ }^{2}$ German Research Institute for Public Administration

\begin{abstract}
This article investigates whether EU accession can help Bulgaria and Romania limit state capture and the undue influence of business actors on the policy process. Particularly vulnerable to such influence, Bulgarian and Romanian institutions are monitored through the EU's co-operation and verification mechanism and the Commission and ECJ infringement procedures. We argue that, under certain conditions, these tools can improve the quality of democracy in both countries. The key conditions are the presence of domestic actors able to use the EU and carry over procedural policy requirements from the acquis to other policy-making. Analysing policy-making processes in the forestry sector, we find NGOs able to use EU links and governments sensitive to naming and shaming can result in a positive influence of EU rules on the policy process and quality of democracy. This is true even in least likely cases, such as non-acquis policy areas in Bulgaria and Romania.
\end{abstract}

\section{Introduction}

Ten years after the initial eastern enlargement, the European Union's ability to support the fragile democracies of its post-communist Member States appears more uncertain than ever (Epstein and Jacoby, 2014). The threat of democratic backsliding seems especially acute for the laggards of the eastern enlargement, Bulgaria and Romania, where state capture and organized crime have undermined democratic institutions and the rule of law. In this article we argue that being part of the EU's multi-level system ensures that EU institutions can act as a final check and balance when national institutions fail. The EU institutions we assess include the co-operation and verification mechanism (CVM) and the EU's regular compliance mechanisms. Furthermore, we examine whether the EU's presence and special attention for democratic rules and procedures can improve the quality of democracy in Bulgaria and Romania by focusing on a less explored dimension of democratic governance: the policy process. We find that even in least likely cases, such as Bulgaria and Romania, and even in a non-acquis policy space, domestic actors can and do use EU rules to improve policy procedures and limit state capture. We further specify the conditions under which such influence is possible.

As Scharpf (1997) has argued, effective problem-solving provides an important aspect of democratic legitimation in the EU. While post-communist democratic institutions at the

\footnotetext{
* The authors would like to thank the participants of the ECPR panel in Tampere, August 2012 and of the workshop 'European Union Enlargement: Ten Years On: Transcending the East-West Divide?' and in particular the discussants Elin Lerum Boasson, Roger Schoenman and John Gould, as well as the two anonymous referees for their helpful comments and suggestions.
} 
macro level, such as political parties or constitutional rules, have been the focus of much scholarly analysis, policy processes have not received much attention from a democratization perspective. Arguably, it is here that joining the EU can make a considerable difference - first, because enlargement's impact has been stronger on policy measures than on the basic constitutional features of politics (Sedelmeier, 2011) and, second, because aspects of the policy process, such as effectiveness and inclusiveness, are particularly vulnerable to state capture and corruption. If the EU's rules and norms can act as safeguards against the dominance of the policy process by one set of actors - for example, business interests - this would help limit state capture and corruption and improve the quality of democracy. For this to happen, other actors need to connect with the EU and use it as a resource to guarantee proper rules and procedures.

To establish whether the EU can indeed play such a role post-accession, we use process tracing to examine two policy processes in Bulgaria and Romania, the new Member States most affected by state capture and corruption. Following Morlino (2009), we conceptualize democratic quality as rooted in the procedural aspects of policy-making and the content and satisfaction of users. A quality democracy is one in which citizens can check the efficacy, responsibility and adherence of governments to rule of law and their accountability to demands expressed by civil society (Morlino, 2009, p. 4). Scharpf's (1997, p. 6) concept of 'output legitimation' - a democracy's ability to solve problems effectively also emphasizes the link between democracy and public policy. If we have effective policies that solve societal problems, it contributes to democratic legitimation and to the quality of democracy (see also Orenstein, 2002). We see a policy process as contributing to the quality of democracy when it takes place according to established formal procedures, delivers quality content (policy, law) and is effective in solving problems. Furthermore, based on existing literature on state capture, we stress the link between the adherence to proper (formal) procedures in the policy process (rule of law) and limiting state capture and corruption.

Building on this definition, we evaluate the EU's role in providing rules for policymaking, in safeguarding the rule of law by acting as a (potential) final instance of appeal when formal consultation procedures are neglected and as a resource for domestic actors seeking to participate in policy-making. We focus on policy processes rather than outcomes, and aim to establish whether the EU can help domestic actors safeguard aspects of the policy process such as public consultation and rule of law. We expect that the EU is potentially able to influence democracy at the policy-making level through two mechanisms. First, it can use rules and sanctions directly. Second, and more important in our cases, the EU can exert an influence in coalition with domestic non-state actors, when such actors hold preferences in favour of EU policies and invoke formal rules in terms of substance or procedure (participation of stakeholders, public consultation mechanisms).

Our analysis focuses on EU environmental policy. We chose this area because it is one where preconditions exist for the EU to influence the policy procedures, as these are embedded in the EU policy itself (Andonova, 2005; Freyburg et al., 2009). The analysis is based on an actor-oriented institutionalist framework that assumes that the existence of EU rules is a necessary, but insufficient condition for quality policy-making. Only if there are domestic actors - at the state or society levels - that seek to use the new rules and involve the EU as a resource for legitimation or sanctions in case of violation, can this result in better policy-making. Actors might use EU rules in two different ways. First, 
formal EU rules pertaining to procedural aspects of policy-making are invoked and become 'rules-in-use' (Ostrom, 1999), leading, if needed, to EU sanctions through the European Court of Justice (ECJ). Second, norms and procedures of better policy-making can spill over to other, non-acquis policy measures, where the EU is used as a political resource by actors interested in maintaining these norms.

The article proceeds as follows. The first part elaborates the connection between the captured state - the biggest challenge to democratic consolidation in the central and eastern Europe (CEE) context - and ineffective, non-transparent policy-making. It then discusses the instruments the EU has introduced post-accession to cope with corruption and state capture. Establishing the limitations of the EU's tools, we discuss the role of domestic actors and their interactions with the EU in the next section. Presenting an actor-oriented institutionalist framework similar to the one developed by Scharpf (1997), we specify the context-specific categories of domestic actors and their role in relation to EU policies. We then use a least likely case selection in which we choose a non-acquis policy measure and test our expectations for improved policy process on two cases of policy-making in the forestry sector in Bulgaria and Romania.

Our choice of countries follows the least likely case logic, as Bulgaria and Romania can be characterized as weak states with weak societies, which, at first sight, might be thought to prevent improvement of the policy process after accession. The variation of green civil society strength between the two countries allows us to establish whether the use of the EU as a resource by strong non-governmental organization (NGO) actors can result in improvements in the policy process despite unfavourable general conditions. Based on this, we can claim that the EU's instruments and the use of the EU by domestic actors can have a positive impact on the quality of democracy in the new Member States under specific conditions.

\section{The EU's Post-Accession Tools for Better Governance in Weak States}

For all the positive expectations linked to joining the EU, citizens in the new Member States cannot be expected to distinguish between EU-related and non-EU-related policymaking. From a citizen's perspective, the EU's monitoring of acquis implementation does not necessarily improve policy-making and governance in general. The patchy character of EU influence is not so problematic in effective states with inclusive and transparent policy processes, but is a problem in weak and captured states. In the following paragraphs, we will discuss briefly the effects of state weakness, capture and corruption on policy-making and the post-accession tools the EU has to counteract such effects.

Despite decades of reform and accession preparations, CEE states, and especially Bulgaria and Romania, remain weak in two key aspects. First, they are still weak in formulating and implementing coherent policies - a weakness long identified in the scholarly literature (cf. Stark and Bruszt, 1998, pp. 112-23). This weakness is especially evident with regard to strategic policy-making capacity and the ability to incorporate feedback and assess the impact of policy measures (World Bank, 2006). Second, state weakness manifests itself as an inability to cope with corruption due to capture (Karklins, 2005). State capture subverts a state's regulatory capacity as networks of entrepreneurs and 'mass political parties' (Innes, 2014) compromise key structures of governance (Ganev, 2007; Hellman, 1998). At the policy level, the undue influence of actors capturing 
state structures - Hellman's 'early winners' in the transformation process - subverts the policy process and biases it towards specific policy outcomes, limiting transparency and the participation of other stakeholders. Such actors act as informal veto players (Dimitrova, 2010), limiting adherence to formal rules and procedures.

EU institutions took notice of informal veto players undermining democratic institutions at the end of the enlargement process when their presence manifested itself as corruption and organized crime. As Innes (2014) argues, processes of post-communist party competition render all post-communist states open to state capture. Bulgaria and Romania have been particularly vulnerable due to weak democratic elites and also lower levels of economic growth that make the state - and post-accession, also the EU attractive targets. To address these threats, the EU instituted a co-operation and verification mechanism $(\mathrm{CVM})^{1}$ as a post-accession oversight tool for Bulgaria and Romania. Thus, in the case of the 'laggard' members of the eastern accession the EU has at its disposal two sets of tools: the non-acquis-based CVM and the 'traditional mechanisms' focusing on policy and enforcement of the acquis (Sedelmeier, 2014).

The CVM was created to encourage judicial reform, the curbing of corruption and organized crime. Initially, it did not appear to have a noticeable impact, partly because negative monitoring reports from the Commission were not linked to sanctions (Spendzharova and Vachudova, 2012; Sedelmeier, 2014). Later, as Spendzharova and Vachudova showed, Member States managed to add some bite to the CVM by using conditionality attached to Schengen area membership and domestic electoral dynamics. The existence of the CVM creates a general context that helps domestic actors limit state capture and improve democratic quality in two ways: first, the CVM's effect is linked to pre-existing political legitimation mechanisms, and second, it provides a focus for the efforts of civil society to hold governments accountable.

Accession to the EU had not only been an all-encompassing policy goal for CEE governments, it was also a source of legitimation for political elites (Fink-Hafner, 1999). The use of the phrase 'returning to Europe' led to rhetorical entrapment not only of the EU leaders who had promised accession (Schimmelfennig, 2001), but also to post-communist politicians. The symbolic and legitimation mechanisms used during enlargement, being normative in nature, survived the pre-accession period. Key politicians continued to use the EU for legitimating domestic reforms. Thus, Boyko Borisov, the leader of the GERB ${ }^{2}$ party that won the 2009 elections in Bulgaria, and Romanian President Traian Băsescu from the Romanian Democratic Liberal Party (PDL), derived their electoral support from pro-European platforms. Such strategic legitimizing actions have been labelled by Woll and Jacquot (2010) 'usage of Europe' (see also Haughton, 2014). But using the EU for legitimation purposes is a two-way process which increases the EU's leverage and makes governments vulnerable to 'naming and shaming' strategies.

The findings of CVM reports and EU criticism in general matter to the extent to which politicians rely on pro-European political legitimation discourses to attract voters. Strategic use of norms by the EU relies on their resonance in the domestic arena and the

\footnotetext{
1 'The purpose of the Cooperation and Verification Mechanism [. . .] is to ensure that administrative and judicial decisions and practices in these areas [...] are in line with the rest of the EU.' The Commission clarifies that judicial reform, fights against organized crime and corruption are crucial for the target states to apply EU law correctly (Commission, 2007).

${ }^{2}$ The Bulgarian abbreviation stands for Citizens for European Development of Bulgaria.
} 
presence of non-state actors interested in using the EU as a political resource (Woll and Jacquot, 2010). Non-state actors have ensured the spread of EU norms and their societal resonance. In 2013, a Bulgarian NGO produced an alternative 'CVM report' to highlight the state of reform in particular areas (Bulgarian Association of Judges, 2013). The Initiative for Clean Justice in Romania has regularly monitored government responses to CVM reports (ICJ, 2008). Thus, both in terms of the CVM and the acquis, the success of EU efforts to promote better governance after accession relies crucially on the preferences and capacities of domestic actors interested in using the formal EU rules (Dimitrova, 2010) and the domestic resonance of EU norms. Building further on the conclusions of the study by Sissenich (2010) that there is a positive correlation between state capacity and civil participation, we believe that a coalition of domestic non-state actors and the EU could compensate for some aspects of state weakness.

A range of studies from the Europeanization literature identifies non-state actors as partners of the EU: NGOs and interest groups. Most civil society organizations in CEE, however, have not yet acquired the organizational capacity and embededness to act as partners of the state in policy-making. Nor have state administrations systematically sought to involve them. This lack of co-operative relationship in policy-making has been identified as problematic by some studies (for example, Börzel and Buzogány, 2010b). Other analyses are more optimistic and suggest that contacts with the EU and the EU's requirements for consultation as part of implementation have strengthened and professionalized certain kinds of NGOs (Andonova, 2005; Börzel and Buzogány, 2010a; Carmin and Fagan, 2010).

A problem somewhat overlooked by the Europeanization literature is that, in a captured state, domestic actors that co-operate with the EU are not the only ones influencing policy-making. As discussed above, business entrepreneurs, sometimes organized as NGOs, but mostly operating informally, are linked closely to state institutions and exert as much, or possibly more, influence on policy-making procedures and outcomes than the NGOs. ${ }^{3}$ The situation of these two sets of actors, however, is often asymmetric in terms of their power and opportunities. Business actors are part of networks penetrating state structures, but they are less likely to be aligned with the EU institutions due to their informal manner of operating and lack of shared norms. Their interests are affected by EU rules, which, if implemented properly, limit their ability to use the structures of the state for personal gain. We assume therefore that NGOs connected to the EU would have an advantage in pursuing their goals when EU-related measures are passed. ${ }^{4}$ Informal veto players, on the other hand, have an advantage in closed policy processes with limited transparency and only symbolic consultation. For the EU to make a difference to democracy at the policy level, it would need to work with local actors promoting meaningful consultation procedures and constrain other actors aiming to capture the policy-making process. This is in line with Jacoby's argument that the EU has an impact through forming coalitions with certain domestic actors while constraining others (Jacoby, 2006, p. 625).

\footnotetext{
${ }^{3}$ To differentiate state captors and NGOs, which are both non-state actors, we define the latter as sector-specific and formally registered, with specific objectives linked to the policy field.

${ }^{4}$ In this article, we do not differentiate between indigenous, grass-roots environmental NGOs and affiliates of large international NGO networks, such as WWF or Greenpeace.
} 


\section{Identifying the Conditions for Using the EU to Improve Governance}

As Radaelli (2012, p. 5) has warned, we should be wary of identifying the EU as the only possible cause of change and reform by focusing our analyses on a narrow, 'Brussels to Bucharest' (or Sofia) pathway. A different perspective is presented by Woll and Jacquot (2010) showing that domestic actors use the EU as a set of opportunities and constraints and transform these in political practices to reach their own goals. When procedural rules specifying the need for consultation and participation are part of the EU's acquis, this still does not ensure improvement in policy processes, as these rules need to be used by domestic actors to become 'rules-in-use' in Ostrom's term (Ostrom, 1999, p. 38). Bearing this in mind, we analyze the configuration and preferences of domestic actors that may invoke and use EU procedural rules.

We build on Woll and Jacquot's (2010) argument that 'usage of EU' should be analyzed as a domestic actor-driven process independent of existing formal institutional arrangements. Their analysis highlights the strategic use of informal EU procedures by domestic actors as a way to trigger domestic reform. We expect that formal rules pertaining to different policy measures can be used by domestic actors in a similar way. The evidence they present that actors move between different sectors or policy levels when using the EU also shapes our expectations about the strategy of environmental NGOs (Woll and Jacquot, 2010, pp. 118-19). We expect that some non-state actors will use the EU to promote better policy-making not only in implementation of the acquis, but also in other policies in the same sector.

Bringing these different insights together, we argue that the improvement of policymaking processes in a specific sector would depend on the strategic interaction between four sets of actors: (1) the EU, the European Commission and the European Parliament; (2) the state (central government and ministries); (3) the sector-specific, transnational or national NGOs; and (4) the non-state business actors - state 'captors' that aim to influence the policy process.

For our case study we select the strongly Europeanized environmental policy sector as a good case for observing these effects of EU membership. Most national policy measures in this field go back to some kind of EU impetus, and there are local non-state actors that can invoke EU rules. EU policy templates strongly emphasize participatory measures (Börzel, 2009). The requirements of EU biodiversity policy, culminating in the establishment of the Natura 2000 Network as envisioned by the Flora-Fauna-Habitats Directive 92/43/EEC imply a considerable opening of biodiversity governance towards more inclusive policy-making (Fairbrass and Jordan, 2001). In contrast to biodiversity policy and in keeping with our least likely case design, forestry policy, which we analyze here, has largely remained a national domain, and thus the EU's direct legal leverage is limited. If we observe EU influence in such non-acquis policy area, either through direct interactions, strategic use of norms or usage of the EU by domestic actors, we can claim that accession has improved the policy process as a whole and thus the quality of democracy.

The forestry law amendments in Bulgaria and Romania are therefore a suitable subcase to explore whether links between the EU and domestic actors have led to changes in the policy process. We look specifically for proper procedure, application of existing formal rules and public consultation as indicators for the improved quality of policy-making defined in the introduction. We start our analysis by establishing the 
sector-specific state-society relations and the differences and similarities between Bulgaria and Romania in environmental policy-making after accession.

\section{Forestry Policy in Bulgaria and Romania}

Our selection of Bulgaria and Romania identifies them as captured states with weak regulating capacity, similar levels of EU influence through the CVM, but differentiated NGO strength. World Bank indicators of state capacity place both countries at the bottom of the EU Member States. Indicators of civil society activism (the European Values Survey) and the environment in which NGOs operate (captured by USAID's NGO Sustainability Index), ${ }^{5}$ show that Bulgaria and Romania have rather weak societies. Focusing on the environmental sector, however, a more nuanced picture emerges. While the regulatory framework of environmental policy and the organizational resources of the state seem to be more or less of similar strength - or, more accurately, weakness - in both countries, we find variation in terms of the presence and strength of green civil society. The number of active environmental NGOs registered in the Regional Environmental Center's directory of NGOs (as of 2004), is somewhat higher in Bulgaria than in Romania, but more importantly, the role of Bulgaria's environmental movement in the country's democratization has been much more prominent. Bulgarian environmental groups, such as Ekoglasnost were among the main drivers of political change before the collapse of communism in 1989-90, whereas in Romania this tradition was largely absent (Botcheva, 1996). Recent surveys suggest that environmental NGOs in Bulgaria have grown in terms of organizational capacity and advocacy (Hristova, 2012, p. 38). Keeping these differences in mind, in the next part of the article, we will trace the two policy processes with a view to evaluating the EU's impact in interaction with domestic actors.

\section{Bulgaria}

\section{The Policy Process}

We begin with an important recent flashpoint, which serves as efficient entry point to a complex set of relationships. In December 2011, an amendment to the existing Law on Forestry in Bulgaria was proposed by the Bulgarian government. ${ }^{6}$ Changes introduced by the draft would increase the exploitation of timber from Bulgarian forests above renewal rates, thereby potentially weakening sustainable forest management and would make certain kinds of construction possible in forest areas, limiting public control over forest territories held by businesses under concession contracts. The attempt to adopt the amendment led to the most significant social mobilization and protests in Bulgaria since the winter of 1997-98. Procedural violations in the adoption of the draft, especially the lack of proper consultation, as well as the content of the proposed amendments were the key issues for protesters.

Forestry legislation in Bulgaria had been introduced in 1997 and amended numerous times since then, almost twice yearly. By 2011, only 10 per cent of forests were in private

\footnotetext{
${ }^{5}$ «http://transition.usaid.gov/locations/europe_eurasia/dem_gov/ngoindex/».

${ }^{6}$ In Bulgarian: 'Законопроект за изменение и допълнение на Закона за горите N 102-01-91 с вносител Министерски съвет'.
} 
hands, but they supplied 20-25 per cent of timber. In 2000-09 there were multiple allegations of swaps of seemingly cheap forest areas belonging to entrepreneurs linked to the government for seaside properties and other areas attractive for development. Corruption allegations against government officials and ministers, who had authorized the swaps, became one of the key issues in the electoral campaign of the GERB movement that won the elections in 2009.

Aiming to avoid over-exploitation and limit informal use of forest areas for swaps, a new law governing forestry areas was passed in February 2011. Yet in December 2011 another draft amendment containing far-reaching changes favourable to timber industry players was proposed. It is this amendment that became the focus of protests and demands for better consultation by domestic NGOs. Passing the law exhibited the typical characteristics of a captured policy process: lack of transparency, fast adoption at first reading, very limited consultation. The mandated period for public consultation during which the parliament and the leading standing committee receive and incorporate submissions from various societal interests fell between Christmas and New Year 2011.

A pre-existing informal coalition of environmental NGOs, called 'For the Nature', intervened at this point and became an increasingly active participant in the debate around the law. ${ }^{7}$ The coalition's representatives explicitly identified citizens' participation and proper consultation as their key objectives (Krustanova, 2012, p. 3) next to substantive changes in the draft limiting the possibilities for illegal exploitation of forest designated areas. The coalition protested against the scheduling of the consultation period and its symbolic character, appearing to aim to avoid proper consultation and citizen involvement. ${ }^{8}$ This did not prevent initial discussions of the draft in the Standing Committee on Agriculture and Forestry of the Bulgarian parliament from taking place in a similarly cursory fashion. The law proceeded to second reading and adoption on 13 June 2012. In this period environmental NGOs and other civil groups mobilized against the amendments and organized an unprecedented protest campaign that combined official actions with peaceful sit-ins and blockages of a major traffic intersection. The conflict around the amendment became a highly politicized issue that remained at the centre of public attention for months (Capital, 2013). ${ }^{9}$

As protests grew, the prime minister met with protesters and representatives of the NGO coalition and promised an open debate of the amendments. Since the amendment had already been adopted, NGOs used the only remaining legal possibility by appealing to the president to use his constitutional right of veto and return the law for further deliberation to parliament. The NGO coalition organized an online petition calling on the president to use his right of veto, which he did, returning the law to parliament ${ }^{10}$ on 15 June 2012. On 27 June 2012, MPs voted to accept the presidential veto, ${ }^{11}$ - at this point supported also by the prime minister. The presidential veto proved to be the turning point, after which consultations were held with a broader group of stakeholders including 'For the Nature' coalition. The final version of the law was adopted on 25 July $2012,{ }^{12}$ without

\footnotetext{
${ }^{7}$ See their website at: «http://www.forthenature.org».

${ }^{8}$ Author interview with an NGO representative, 8 May 2012.

${ }^{9}$ Based on Google trends data.

${ }^{10}$ Presidential powers are limited in the constitution and the veto is conditional and can be rejected by parliament.

${ }^{11}$ The vote record showed five votes in favour, 84 abstentions and 38 against.

${ }^{12}$ State Gazette, No. 60, July 2012.
} 
most of the controversial amendments challenged by the 'For the Nature' coalition. As a whole, the outcome was considered a success by the environmental coalition. Their opponents appeared to see the amendments as unfavourable, as they declared in a press conference in August 2012 that the law was unworkable and that they would appeal to the European Commission.

\section{Strategic Use of EU Rules by Civil Society}

The EU played an important role in increasing the organizational capacity and professionalization of environmental NGOs which continued after accession (Andonova and Tuta, 2011; Krustanova, 2012). Even though the impulse for protests around the forestry law amendment clearly came from the environmental NGOs themselves, they were strengthened by their interactions with the EU in terms of capacity-building and by using formal EU procedures and sanctions (where possible) or invoking 'Europe' as suggested by Woll and Jacquot (2010). The following paragraphs briefly illustrate these different mechanisms.

In terms of capacity-building, the coalition 'For the Nature' came together as a result of the involvement of the NGOs in the establishment of the EU's Natura 2000 network and subsequent actions to protect designated nature preservation areas. Pre-accession, members of some of the $\mathrm{NGOs}^{13}$ had carried out a substantial part of the expert work involved in the definition, specification and mapping of areas for nature preservation for the Natura 2000 network. Both interview data and other analyses (Krustanova, 2012) find that the NGOs used the lessons learned from previous campaigns in the forestry campaign. NGOs had also learned from their collaboration with the EU: in a survey, they listed 'referring to EU institutions as an opportunity to influence national ones' among key advocacy techniques (Hristova, 2012, p. 65).

NGOs used the EU by providing input for CVM reports or signalling possible infringement cases related to EU environment acquis, but also rules on state aid. Evidence of these interactions can be found in the Commission's CVM reports, one of which directly addressed forest land swaps (but not the amendment analyzed here). The 2009 report stated:

The Commission notes that laws which should prohibit abuse of land and forest swaps enter into force as of 1 February (forests) and 1 March (land). The Commission will continue to closely monitor the effective implementation of these laws. (Commission, 2009)

In an interview, NGO representatives listed contacts with the European Commission and, post-2007, with Green MEPs as ways to mobilize political pressure and force government to stop illegal practices. According to the same expert, Bulgarian institutions (the government and parliament) have been sensitive to reputational losses incurred by infringement procedures covered by Bulgarian media. ${ }^{14}$ The GERB government, which resigned in February 2013 in reaction to continuing protests, was also sensitive to sanctions such as the suspension of EU funding programmes. In short, in the words of the same expert, the strategy of NGOs can be subsumed as 'we resolve Bulgarian problems by presenting them as European ones'.

\footnotetext{
${ }^{13}$ Members of the NGOs Bulgarian Society for the Protection of Birds, Balkani and the Biodiversity Foundation.

${ }^{14}$ Author interview with an NGO expert, 26 July 2012.
} 


\section{Other Players: Entangled with the State}

As discussed above, other non-state actors involved in business and connected to state structures, difficult to capture as they are, have an important influence on policy-making in the post-communist context (Dimitrova, 2010). In the case of Bulgaria, indirect evidence of non-state actors laundering money through tourism development projects has been mentioned in the European Commission's CVM monitoring report of July 2012. Specific cases of business entrepreneurs working in parliament and pushing specific amendments were exposed by investigations of the Parliamentary Commission for Prevention and Ascertainment of Conflict of Interest. Specifically, the deputy chairman of the Agriculture and Forests Committee (dealing with the law), was investigated and found guilty of conflict of interest on two separate counts. ${ }^{15}$

The involvement of entrepreneurs closely linked to state structures became increasingly visible during the forestry amendment policy process. Three different groups of actors emerged to defend the controversial forestry amendments during the additional consultations. The first - the private forest owners - argued in a submission to parliament during the post-presidential-veto consultations that provisions allowing wood cutting to up to 80 per cent above replacement levels were necessary to guarantee their rights to dispose of their property. The second group defending the amendments of the forestry law, led apparently by the impression that they would promote tourism, were local government representatives from mountain areas. They participated in a so-called 'counter-protest', although, according to interviews, some mayors had ordered local civil servants to protest and bussed them to the capital. The third actor was an offshore registered company with murky ownership, 'Vitosha ski', holding a concession for operating the ski lifts at the Vitosha Mountain near the capital. They argued for amendments facilitating the developments of new lifts and using forest territories as ski resorts. Known for their personal links to the prime minister, they were the most active advocates of the amendments, as shown by the publicly available minutes of the additional consultations.

\section{Changes in the Policy Process: Limiting State Capture through Wider Consultations}

The NGO's mobilization of a broad group of young and educated protesters able to propose alternative policy solutions stopped the forestry amendment, but also constrained state capture by advocating and getting more transparent policy procedures. Evidence of the environmental actors' process-related preferences (in terms of formal procedures, rule of law and transparency) can be found in the minutes of the additional consultations published online in their entirety. Such a record of participants and their positions is in stark contrast to the anonymity of 'state captors', participants influencing the earlier drafting of the law and is nearly unprecedented for Bulgarian state institutions. The first request of the representatives of the environmental coalition in the consultations was observance of legal procedures instead of 'secret informal deals'. The last of the consultation meetings exhibited the features of a real - and not just symbolic - consultation, with all interested stakeholders explicitly identified and presenting their positions.

The government's openness to these meetings and to extending the consultation period and the drafting procedure was clearly linked to the ruling party's pro-EU political

\footnotetext{
${ }^{15}$ According to an investigation in Capital weekly (Gospodinova, 2012).
} 
platform and legitimation. Furthermore, environmental issues clearly had broad societal resonance. In January 2013, the regular sociological survey tracking electoral attitudes identified the unauthorized development permitted by local and national authorities in Natura 2000 areas at the Bulgarian seaside as one of the top three most negatively perceived actions of the government.

What effect did all this activity have on the quality of the policy-making process? Our initial expectation that the EU would be directly involved and invoke the CVM was not confirmed. The controversial policy measure was simply not part of the EU's acquis. By contrast, the second mechanism of EU influence we outlined - concerned actors using the EU as a strategic resource - was observed. Ultimately, the policy process around the forestry amendment in Bulgaria was improved in two crucial aspects: rule of law and consultation.

\section{Romania}

\section{The Policy Process}

Paralleling in many ways developments around the same time in neighbouring Bulgaria, in 2011 a cross-party coalition of Romanian MPs with intimate ties to the timber industry introduced a legislative initiative aiming to replace existing forest legislation with a so-called 'New Forest Code'. ${ }^{16}$ The changes proposed by this all-party coalition were highly controversial and included the possibility of increasing the volume of timber exploitation, weakening principles of sustainable forest management and easing re-zoning of forested areas so that they could be used commercially. After the initiative had passed through the Senate without being discussed in depth, the Agriculture and Forests Committee of the House of the Representatives approved the proposal after a public hearing that excluded organizations critical of the initiative (WWF Romania, 2012).

The passing of the New Forest Code was the latest stage in almost two decades of perpetual redrafting of Romania's forestry legislation. Several waves of land property restitutions resulted in transferring two-thirds of the overall forested territory in Romania from state to private or local public ownership. This massive change in the ownership structures was followed by the emergence of new actors, such as private forest owners, but also environmental NGOs in the forestry sector, hitherto under strong state control (Novac and Auer, 2004).

While the New Forest Code was met with criticism in parts of academia and among civil society organizations, no sweeping public protests that could be compared to those in Bulgaria were witnessed. It was rather the change of the government in April 2012 and the political crisis unfolding in the following months that postponed passing the amendments. Parallel to this development, nature protection legislation adopted in the context of Romania's EU accession became increasingly relevant for forested territories as these harbour species and habitats subject to the EU's Natura 2000 directives. Following the spillover logic outlined above, this allowed environmental organizations to get their foot in the door of what had been a highly opaque forestry policy. In March 2013, responding to criticism by civil society organizations, the new government unexpectedly withdrew the draft from parliament and initiated a new, more open consultation process to be carried out

\footnotetext{
${ }^{16}$ In Romanian: Proiectul de Lege pentru modificarea şi completarea Legii nr. 46/2008 - Codul silvic (PL.x 573/2011).
} 
in 2013. The new consultations included different groups of stakeholders, such as forest owners, environmental organizations and trade unions active in the forestry field. Thus, even if to a lesser extent than in the Bulgarian case, we find evidence of increased consultation and more transparency in Romanian forestry policy.

\section{Strategic Use of EU Rules by Civil Society}

Civil society organizations have been the key players supporting the domestic implementation of EU nature protection directives in Romania. The Romanian offices of WWF and Greenpeace became central actors co-ordinating the work of the 'NGO Coalition Natura 2000' ('Coaliţia ONG Natura 2000 România'). Especially WWF Romania, led by the former liberal MEP Magor Csibi, became involved in lobbying on nature conservation matters both in Bucharest and Brussels.

Just as in Bulgaria, working with the European Commission has strengthened NGOs' advocacy and networking capacity (Andonova and Tuta, 2011; Parau, 2009). Environmental NGOs repeatedly put the government under pressure by providing the European Commission with information on violations connected to the Natura 2000 sites. During the designation process of protected sites, the European Commission has regularly followed the view of NGOs against the government's position and declared the list of protected sites proposed by the Romanian government incomplete. The exclusion of sites proposed by the NGOs from the official list of protected sites resulted in the EU launching the first infringement procedure on environmental policy against Romania. The Commission remained active in monitoring the implementation process beyond the formal legal procedure and carried out an unexpected field visit in 2012 to check details of the designation process. ${ }^{17}$

Civil society mobilization against the New Forest Code could build on the networks and expertise forged during the Natura 2000 campaigns. WWF, Greenpeace and more than 70 grass-roots environmental organizations brought media attention to the initially secretive parliamentary debates on the forestry amendment by pointing to the vested interests behind it. They exerted pressure on individual MPs by using media and direct mail campaigns. In the context of the campaign, Greenpeace carried out a larger scientific study highlighting the significant degradation of forested territory during the two decades since regime change (Greenpeace Romania, 2012). WWF Romania presented a full-fledged alternative draft of the legislation with detailed description of the potential problems and alternatives. $^{18}$

In contrast to the Bulgarian case, forestry policy was not mentioned in the CVM reports. However, the NGO Coalition used the EU in the campaign by creatively linking forestry issues to the question of 'good governance' - a recurring topic in Romania in the context of the CVM. Their strategy was to connect the issue of forestry to the broad discourse about the causes of corruption and refer to EU criticism. Referring to allegations of corruption in the forestry sector secured a wider audience than could be achieved by mobilizing citizens on environmental issues. Furthermore, forestry policy was targeted not only by environmental NGOs, but also by some of Romania's most important

\footnotetext{
${ }^{17}$ Author interview with an environmental NGO, 21 February 2013.

${ }^{18}$ The document can be found at: «http://awsassets.panda.org/downloads/amendamente_cod_silvic_final_05_11_2012_1 doc».
} 
anti-corruption NGOs and think tanks, such as the Romanian Academic Society, which helped advance the 'cognitive usage' (Woll and Jacquot, 2010, p. 117) of references to EU membership to secure public attention.

\section{Other Players: A Fusion between Business and State Structures}

The partial privatization of Romanian forested territory has resulted in blurred ownership structures best described by Stark and Bruszt's (1998) term 'recombinant property', referring to situations where assets are transferred into private firms but liabilities remain state property. The National Forest Administration Romsilva, which not only manages state forests, but is also the regulator of the field, became a vehicle for extraction of rents by its politically nominated leadership. Romsilva was regarded as the main culprit behind the dramatic rise in illegal logging during the last decade, resulting in irreparable losses in forested territories. Its leadership has been accused of illegally contributing to campaign budgets of governing parties and of corrupt decisions in numerous local and national public procurement cases. For example, in a much publicized case, the Supreme Court of Justice acquitted the head of Romsilva of causing several millions worth of financial damage by buying uniforms (including Versace tiepins) for all foresters in Romania at highly inflated prices (Nutu et al., 2011). MPs with financial interests in the wood processing sector, often described as 'timber barons', could trade their contacts to government, other state institutions and the judiciary for privileged access to information or protection from prosecution. Among the MPs initiating the New Forest Code, cases of conflict of interest were abundant: businessmen elected as politicians and acting as regulators included the chair and the rapporteur in the Agriculture and Forest Standing Committee. It is exactly this kind of political influence over state institutions that the EU has tried to constrain through the CVM.

EU rules and their usage seem to have recently contributed to some loosening of the 'unholy' coalition between state institutions and private business interests. Increasingly, environmental organizations are using litigation before Romanian domestic courts. Using EU-inspired access to information legislation, Greenpeace Romania was successful in gaining access to documents justifying the clearing of forested territories. ${ }^{19}$ Further institutional changes within Romanian forestry were triggered by the country's significant problems in implementing the Natura 2000 Directive (Buzogány, 2009). These problems prompted the European Commission to initiate a 'functional review' of Romania's environmental management system, which revealed unclear division of competencies and suggested the need for a thorough reform of Romsilva (World Bank, 2011). Therefore, while the EU has had no direct leverage over forest policy, external influence on the sector has been exerted as a spillover from other, more Europeanized policy fields.

Market opening and property restitution have also brought powerful new actors into the forestry sector, leading to the acquisition of large portions of forested territory by foreign investors. Proforest, the lobby group representing the largest foreign-owned timber companies has established intimate ties with Romsilva and the Ministry of Environment and Forests. However, their position and access to state structures are not uncontested as actors

\footnotetext{
${ }^{19}$ Greenpeace: «http://www.greenpeace.org/romania/ro/campaigns/schimbari-climatice-energie/paduri/activitati/proces -castigat-pentru-paduri/».
} 
in the field of forestry policy have multiplied as the forest restitution process created about 830,000 forest owners, represented by a large number of organizations, with diverse members and interests.

\section{Process Change: Usage of EU Links by All Actors}

In contrast to the big players in forestry business, such as Romsilva and Proforest, the access of small private forest owners to the policy-making process around the New Forest Code was restricted. However, just like the environmental organizations connected to EU-level networks, these organizations established and used contacts with sectoral organizations of small forest owners at the EU level, such as Confederation of European Forest Owners. In the New Forest Code debates, they referred to Romania's need to cope with EU forestry regulations ('legitimizing usage' in Woll and Jacquot's [2010, p. 117] terminology). The Association of Forest Owners in Romania (an umbrella organization of local and county associations and Federation Nostra Silva) has argued that EU agricultural aid schemes for protected territories under the Natura 2000 network or the so-called 'Illegal Timber Regulation(995/2010) have to be implemented to prevent infringement proceedings (Ionescu, 2011). While deliberations on the new draft of the forestry law, initiated in early 2013, have not been completed, some EU-related arguments have clearly been taken up by government officials charged with reformulating the policy (Capital, 2013).

Summarizing the Romanian case study, we find fewer clear signs of improved transparency and increased consultation than in Bulgaria, but we could detect at least some development towards adherence to formal rules. While the coalition between state actors and business interests still seems to be controlling the policy process, there has been an emergence of new actors - foreign investors, who, at least on the formal level, accept a higher level of transparency and consultation. This gradual procedural change was also driven by environmental organizations and owner associations, which strategically linked their protest to the EU's anti-corruption agenda and tried to capitalize on overlaps of forestry policy with established EU policies in nature conservation.

\section{Conclusions}

The policy-making processes analyzed in the second part of this article provided abundant evidence of interactions between the EU and non-state actors in both Bulgaria and Romania. In both countries, the pro-environment coalitions not only engaged with the implementation of environmental rules, but also carried over procedural requirements potentially limiting state capture to other policy measures. With their transnational links and increased expertise and capacity, environmental NGOs served as conduits for norm diffusion and participated in two-level games in which they sought to use EU rules and involve the EU or other international actors to change policy practices and prevent or limit effective state capture, which was a constant threat in this policy domain.

We documented variation in the degree to which the interactions between the EU and these actors have brought improvements in the procedural aspects of the policy processes in our two cases. In Bulgaria, the environmental activists built on their long tradition of political mobilization to successfully open up the policy process on the forestry law, while 
in Romania, large forestry business kept a stronger position at the national level. In Bulgaria NGOs ultimately prevented the adoption of controversial aspects of the forestry law promoting business interests, while in Romania the process of redrafting continues and outcomes are uncertain. Nevertheless, even in Romania we have seen increasing pluralism, where state captors are increasingly challenged by smaller forestry owner associations and environmental organizations. This could not have happened in either country if governments had not previously relied on pro-European legitimation mechanisms and been sensitive to EU criticism in the CVM context. Thus, we find that a multi-level, multi-actor framework that takes into account both government legitimation strategies and civil society strength can help predict how effective the EU can be to promote good governance post-accession.

The most important conclusion of our case studies is that even in least likely cases of a non-acquis policy area in states with weak capacities, we can still find domestic actors able to instrumentalize EU tools to improve the policy process. Thus, the impact of the EU on democratic quality in terms of the policy process cannot be ignored. The possibility of appealing to the EU when the formal rules of procedure and possibilities for consultation are circumvented is an important aspect of the development of democratic governance in these states. In this regard, and in contrast with Innes (2014) and Sedelmeier (2014), we find that the EU has provided an opportunity to CEE actors to promote policy procedural aspects of democratic governance. While we cannot generalize based on these two cases, it is reasonable to expect that such processes of sectoral spillover of norms, initiated by interested domestic actors, can help close the gap between eastern and western Member States (Epstein and Jacoby, 2014). This possibility is conditional, however, on support for the EU remaining strong among the broader public.

Correspondence:

Antoaneta L. Dimitrova

Institute of Public Administration

Leiden University

Postbus 13228

2501 EE Den Haag

The Netherlands

email: a.l.dimitrova@cdh.leidenuniv.nl

\section{References}

Andonova, L.B. (2005) 'The Europeanization of Environmental Policy in Central and Eastern Europe'. In Schimmelfennig, F. and Sedelmeier, U. (eds) The Europeanization of Central and Eastern Europe (Ithaca, NY: Cornell University Press).

Andonova, L.B. and Tuta, I.A. (2011) 'Greener Together? Transnational Networks and Paths of Environmental Compliance in Europe'. Paper presented at the LSEE-KFG Environmental Governance workshop, London, 6 May.

Börzel, T.A. (ed.) (2009) Coping with Accession to the European Union: New Modes of Environmental Governance in Southern, Central and Eastern Europe (London: Palgrave Macmillan).

Börzel, T.A. and Buzogány, A. (2010a) 'Environmental Organisations and the Europeanisation of Public Policy in Central and Eastern Europe: The Case of Biodiversity Governance'. Environmental Politics, Vol. 19, No. 5, pp. 708-35. 
Börzel, T.A. and Buzogány, A. (2010b) 'Governing EU Accession in Transition Countries'. Acta Politica, Vol. 45, No. 1-2, pp. 158-82.

Botcheva, L. (1996) 'Focus and Effectiveness of Environmental Activism in Eastern Europe: A Comparative Study of Environmental Movements in Bulgaria, Hungary, Slovakia and Romania'. Journal of Environment and Development, Vol. 5, No. 3, pp. 292-312.

Bulgarian Association of Judges (2013) Judicial Reform Assessment (Bucharest: Bulgarian Association of Judges). Available at: «http://www.judgesbg.org/?m=11\&id2=397».

Buzogány, A. (2009) 'Romania: Environmental Governance - Form without Substance'. In Börzel, T. (ed.).

Capital (2013) 'Lucia Varga: "Codul silvic va fi modificat în mod radical". Capital. Available at: «http://www.capital.ro/detalii-articole/stiri/lucia-varga-codul-silvic-va-fi-modificat-in-mod -radical-182170.html».

Carmin, J. and Fagan, A. (2010) 'Environmental Mobilisation and Organisations in PostSocialist Europe and the Former Soviet Union'. Environmental Politics, Vol. 19, No. 5, pp. 689-707.

Commission of the European Communities (various years) 'Report from the Commission to the European Parliament and the Council on progress in Romania/Bulgaria under the cooperation and verification mechanism'. Documents: $\operatorname{COM(2007)} 377$ final; $\operatorname{COM(2007)} 378$ final; $\operatorname{COM}(2008) 62$ final; $\operatorname{COM(2008)} 63$ final; $\operatorname{COM(2008)~494;~} \operatorname{COM}(2008) 495$ final; $\operatorname{COM}(2009) 402$ final.

Dimitrova, A.L. (2010) 'The New Member States in the EU in the Aftermath of Accession: Empty Shells?' Journal of European Public Policy, Vol. 17, No. 1, pp. 137-48.

Epstein, R. and Jacoby, W. (2014) 'Eastern Enlargement Ten Years On: Transcending the EastWest Divide?' JCMS, Vol. 52, No. 1, pp. 1-16.

Fairbrass, J. and Jordan, A. (2001) 'Protecting Biodiversity in the European Union: National Barriers and European Opportunities?' Journal of European Public Policy, Vol. 8, No. 4, pp. 499-518.

Fink-Hafner, D. (1999) 'Dilemmas in Managing the Expanding EU: The EU and Applicant States' Points of View'. Journal of European Public Policy, Vol. 6, No. 5, pp. 783-801.

Freyburg, T., Lavenex, S., Schimmelfennig, F., Skripka, T. and Wetzel, A. (2009) 'EU Promotion of Democratic Governance in the Neighbourhood'. Journal of European Public Policy, Vol. 16, No. 6, pp. 916-34.

Ganev, V. (2007) Preying on the State: The Transformation of Bulgaria after 1989 (Ithaca, NY: Cornell University Press).

Gospodinova, V. (2012) 'Minister in the Shadow' (in Bulgarian: 'Ministur v syanka'). Capital, 24 August. Available at: «http://www.capital.bg/politika_i_ikonomika/bulgaria/2012/08/24/ 1894565_ministur_v_sianka/».

Greenpeace Romania (2012) 'Romania Cuts Down 3 Hectares of Forest Per Hour!' Available at: «http://www.greenpeace.org/romania/ro/campanii/schimbari-climatice-energie/paduri/ activitati/Romania-cuts-down-3-hectares-of-forest-per-hour/».

Haughton, T. (2014) 'Money, Margins and the Motors of Politics: The EU and the Development of Party Politics in Central and Eastern Europe'. JCMS, Vol. 52, No. 1, pp. 71-87.

Hellman, J.S. (1998) 'Winners Take All: The Politics of Partial Reform in Postcommunist Transitions'. World Politics, Vol. 50, No. 2, pp. 203-34.

Hristova, D. (2012) 'Civil Society in Bulgaria: NGOs versus Spontaneous Civic Activism?' Bulgarian report for the study 'Has our Dream Come True? Comparative Research of Central and Eastern European Civil Societies' (Sofia: Open Society Institute).

Initiative for Clean Justice (ICJ) (2008) 'Early Warning Report: Initiative for Clean Justice' (Bucharest: Romanian Academic Society). 
Innes, A. (2014) 'The Political Economy of State Capture in Central Europe'. JCMS, Vol. 52, No. 1, pp. 88-104.

Ionescu, M. (2011) 'Apel pentru necesitatea aplicării legislatiei în vigoare pentru gestionarea durabilă a pădurilor din România'. Progresul Silvic, pp. 117-28.

Jacoby, W. (2006) 'Inspiration, Coalition and Substitution: External Influences on Postcommunist Transformations'. World Politics, Vol. 58, No. 4, pp. 623-51.

Karklins, R. (2005) The System Made Me Do It: Corruption in Post-Communist Societies (Armonk, NY: M.E. Sharpe).

Krustanova, R. (2012) Zelenoto dviozhenie I zhelenite v Bulgaria: Mezhdu integracia v sistemata I sistemna promyana (Bucharest: Friedrich Ebert Stiftung Bulgaria).

Morlino, L. (2009) 'Qualities of Democracy: How to Analyse Them'. Working Paper (Florence: Instituto Italiano de Scienze Umane).

Novac, C. and Auer, M. (2004) 'Forestry Resources in Transition: The Romanian Experience'. In Auer, M. (ed.) Restoring Cursed Earth: Appraising Environmental Policy Reforms in Central and Eastern Europe and Russia (Lanham, MD: Rowman \& Littlefield).

Nutu, O., Stefan, L., Mungiu-Pippidi, A. and Ionita, S. (2011) 'Beyond Perception: Has Romania's Governance Improved after 2004?' Romanian Journal of Political Sciences, No. 1, p. 4-27.

Orenstein, M.A. (2002) 'Quality of Democratic Policy Processes in Central and Eastern Europe and the Former Soviet Union'. Paper presented to the American Political Science Association Annual Meeting, Boston, MA, 29 August-2 September.

Ostrom, E. (1999) 'Institutional Rational Choice: An Assessment of the Institutional Analysis and Development Framework'. In Sabatier, P.A. (ed.) Theories of the Policy Process (Boulder, CO: Westview Press).

Parau, C.E. (2009) 'Impaling Dracula: How Accession Empowered Civil Society in Romania'. West European Politics, Vol. 32, No. 1, pp. 119-41.

Radaelli, C.M. (2012) 'Europeanization: The Challenge of Establishing Causality'. In Radaelli, C.M. and Exadaktylos, T. (eds) Research Design in European Studies: Establishing Causality in Europeanization (Basingstoke: Palgrave Macmillan).

Scharpf, F. (1997) Games Real Actors Play: Actor-Centered Institutionalism in Policy Research (Boulder, CO: Westview Press).

Schimmelfennig, F. (2001) 'The Community Trap: Liberal Norms, Rhetorical Action and the Eastern Enlargement of the European Union'. International Organization, Vol. 55, No. 1, pp. 47-80.

Sedelmeier, U. (2011) 'Europeanisation in New Member and Candidate States'. Living Reviews in European Governance, Vol. 6, No. 1. DOI: 10.12942/lreg-2011-1.

Sedelmeier, U. (2014) 'Anchoring Democracy from Above? The European Union and Democratic Backsliding in Hungary and Romania after Accession'. JCMS, Vol. 52, No. 1, pp. 105-21.

Sissenich, B. (2010) 'Weak States, Weak Societies: Europe's East-West Gap'. Acta Politica, Vol. 45, No. 1-2, pp. 11-40.

Spendzharova, A.B. and Vachudova, M.A. (2012) 'Catching Up? Consolidating Liberal Democracy in Bulgaria and Romania after EU Accession'. West European Politics, Vol. 35, No. 1, pp. 39-58.

Stark, D.C. and Bruszt, L. (1998) Postsocialist Pathways: Transforming Politics and Property in East Central Europe (Cambridge: Cambridge University Press).

Woll, C. and Jacquot, S. (2010) 'Using Europe: Strategic Action in Multi-level Politics'. Comparative European Politics, Vol. 8, No. 1, pp. 110-26.

World Bank (2006) EU-8: Administrative Capacity in the New Member States - The Limits of Innovation (Washington, DC: World Bank). 
World Bank (2011) Functional Review of Romania's Environment, Water and Forest Sector (Bucharest: Jaspers Consulting).

WWF Romania (2012) 'Forest Act Amendments would Legalise Exploitation of Romanian Forests'. Available at: «http://wwf.panda.org/?207057/Forest-Act-amendments-would-legalise -exploitation-of-Romanian-forests». 